Kapata Arkeologi, 13(2), 179-194

ISSN (cetak): 1858-4101

ISSN (elektronik): 2503-0876

http://kapata-arkeologi.kemdikbud.go.id

\title{
KERAJAAN LOLODA: MELACAK JEJAK ARKEOLOGI DAN SEJARAH
}

\section{Loloda Kingdom: History and Archaeological Traces}

\author{
Wuri Handoko \\ Balai Arkeologi Maluku - Indonesia \\ Jln. Namalatu-Latuhalat, Nusaniwe, Ambon 97118 \\ wuri_balarambon@yahoo.com \\ Naskah diterima: 22/08/2017; direvisi: 10/11—20/11/2017; disetujui: 22/11/2017 \\ Publikasi elektronik: 30/11/2017
}

\begin{abstract}
A few historical source mention the Kingdom of Loloda as one of the great kingdoms of North Maluku, contemporaneous with the four Islamic kingdoms that developed into sultanates, namely Ternate, Tidore, Bacan and Jailolo. However, compared to these powers, the development of Islamic rule in Loloda is not well known through historical sources, and the kingdom is even said to have collapsed in the early 20th century. In this article I discuss the results of research to trace archaeological evidence about the history of the Kingdom of Loloda. Starting with literary sources, I then describe the results of archaeological surveys in the area mentioned in historical text and public information. Archaeological surveys indicate that the center of the Loloda kingdom was located in the Loloda watershed in Loloda Sub-district, Halmahera Barat District. Archaeological research results suggest the Kingdom of Loloda grew from the 16th century and experienced collapse at the time of European colonialism.
\end{abstract}

Keywords: Loloda, kingdom, history, archaeology, Islam, colonialism

\begin{abstract}
Abstrak
Kerajaan Loloda dalam teks sumber sejarah yang terbatas, disebut-sebut sebagai salah satu kerajaan besar di Maluku Utara, sezaman dengan empat aliansi kerajaan Islam yang berkembang menjadi kesultanan yakni, Ternate, Tidore, Bacan, dan Jailolo. Namun dibanding keempat kekuasaan Islam itu, Loloda tidak diketahui perkembangannya, bahkan disebut runtuh pada awal abad 20 dan hilang dalam catatan sejarah perkembangan kekuasaan Islam. Penulisan ini berdasar pada hasil penelitian untuk melacak bukti-bukti arkeologi tentang sejarah Kerajaan Loloda. Dimulai dari pengumpulan sumber literatur, kemudian dilanjutkan dengan survei arkeologi di wilayah yang disebut dalam teks sejarah dan informasi masyarakat. Berdasarkan hasil survei arkeologi, diketahui adanya lokasi yang menjadi indikasi pusat kerajaan Loloda di DAS (daerah aliran sungai) Loloda di Kecamatan Loloda Kabupaten Halmahera Barat. Hasil penelitian arkeologi menggambarkan bahwa Kerajaan Loloda berkembang pada abad 16 dan mengalami keruntuhan sesudahnya ketika kolonialisme bangsa Eropa berkembang di wilayah itu.
\end{abstract}

Kata Kunci: Loloda, kerajaan, sejarah, arkeologi, Islam

\section{PENDAHULUAN}

Dalam berbagai catatan sejarah, disebutkan bahwa Loloda adalah sebuah nama kerajaan di wilayah Maluku Utara, terletak di sebuah tanjung di Pulau Halmahera bagian barat dan bagian utara. Kerajaan ini dianggap sebagai kerajaan yang sudah berdiri sejak abad 13, sebagai bekas kerajaan pertama, tertua, dan terbesar di kawasan laut dan kepulauan Maluku bagian utara. Dalam beberapa sumber asing dan lokal, setelah abad 17 kerajaan ini sudah hilang, sehingga sudah sangat jarang disebut-sebut dalam banyak referensi sejarah (Amal, 2010: 6; Rahman, 2015: 206). Dalam buku yang ditulis Andaya (1993, 2015), dikatakan bahwa Loloda adalah sebuah wilayah kerajaan yang mengakui kekuasaan Ternate sebagai wilayah pusat. Dengan demikian, Loloda adalah wilayah taklukan atau wilayah vassal dari 
Ternate. Menurutnya, pada masa lalu Loloda dianggap kerajaan yang cukup kuat. Namun menurut Galvao, Loloda adalah sebuah desa kecil yang kacau dan masa lalunya hanya tinggal kenangan. Pada tahun 1686, Belanda menyebut Loloda sebagai desa yang terletak di tepi sungai dengan air payau. Loloda merupakan kampung muslim, di sana raja dan ibunya tinggal dan 5 (lima) desa Alifuru yang terletak di pedalaman Loloda (Amal, 2010: 126-127; Andaya, 2015: 110-112). Meskipun pernah dikenal sebagai kerajaan Islam, namun Loloda tidak terkonfigurasi ke dalam Motir Staten Verbond (Persekutuan Raja-Raja Maluku, 1322-1343), dan tidak pernah terdengar sebagai kerajaan Islam dengan raja yang bergelar Sultan (Rahman, 2015: 208). Kerajaan ini dianggap hilang tak berbekas pada sekitar tahun 1900 an, akibat kalah bersaing dengan pihak kolonial. Tahun 1908, ketika terjadi perang dengan Belanda, Loloda mengalami kekalahan.

Penelitian ini adalah penelitian arkeologis untuk menelusuri jejak Islamisasi dan perkembangannya di wilayah Loloda. sebagai kekuasaan Islam yang meredup bahkan runtuh pada awal abad 20. Tema penelitian arkeologi sejarah Islam yang paling umum adalah menyangkut perkembangan pengaruh dan penyebaran Islam. Namun untuk kasus Maluku, masalah penyebaran Islam merupakan fenomena yang kompleks. Hal ini karena perluasan kekuasaan Islam dilakukan dalam mobilitas tinggi, dan bersaing pengaruh dengan pihak kolonial. Persaingan pengaruh kekuasaan dari Kesultanan Ternate dengan pihak kolonial, terutama dalam perebutan geopolitik dan geoekonomi, mempengaruhi tumbuh dan berkembangnya Islam (Handoko, 2008: 3-5, 11; Handoko, 2009: 19; Handoko, 2017: 96).

Islamisasi di wilayah Maluku Utara, tidak bisa dilepaskan dari sejarah Islamisasi di Ternate dan Tidore. Kesultanan Ternate tampil menjadi penguasa Islam yang paling dominan di Maluku Utara, yang kekuasaannya menyebar di berbagai wilayah, bahkan hingga ke wilayah bagian selatan Kepulauan Maluku, yakni Maluku Tengah, meliputi Pulau Seram dan Pulau Lease, bahkan tetap bertahan hingga sekarang (Putuhena, 2001: 62-66; Leirissa, 2001: 8; Handoko, 2017: 95). Banyak penulisan sejarah Maluku berisi pula berbagai penjelasan menyangkut sejarah penyebaran Islam di wilayah ini. Banyak kajian menjelaskan tentang sejarah Islamisasi di wilayah Maluku antara lain meliputi, proses penyebaran Islam, negara penyebar, dan proses penerimaan hingga perkembangannya. Meski demikian,

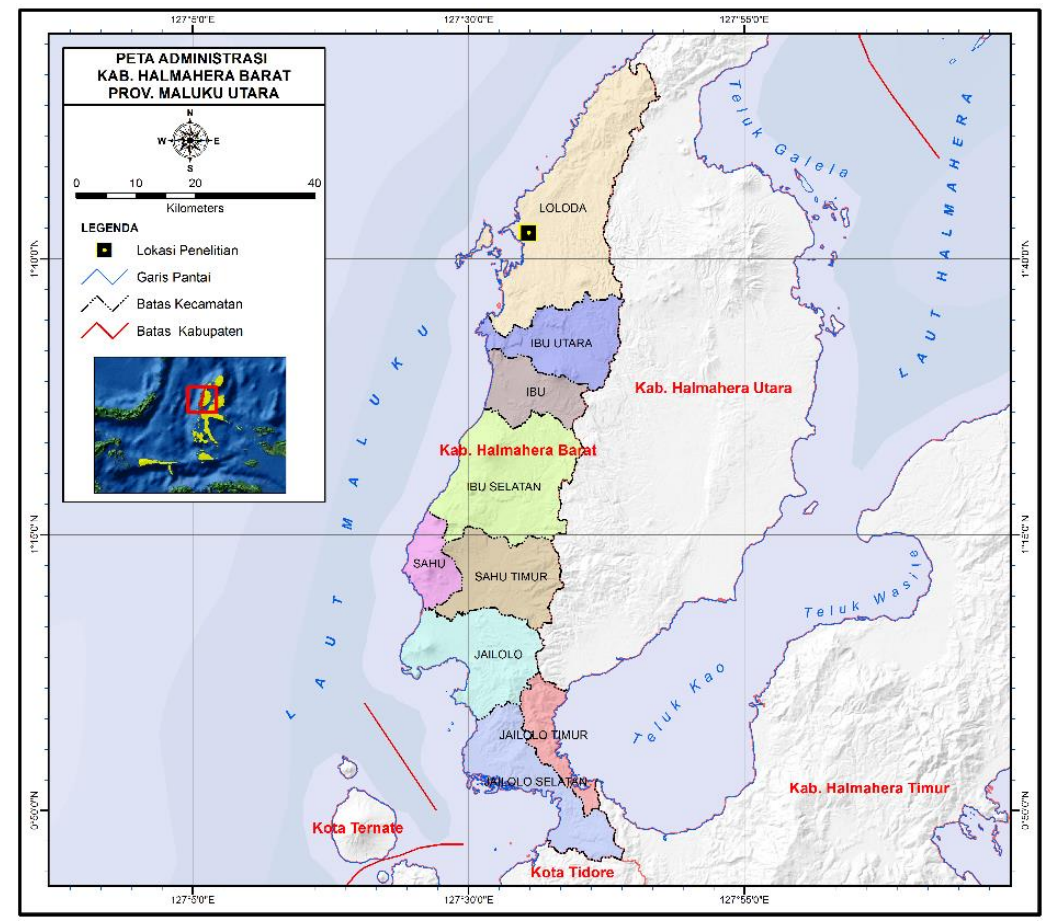

Gambar 1. Peta Administratif Kabupaten Halmahera Barat. Lokasi situs berada di wilayah Kecamatan Loloda, Kabupaten Halmahera Barat.

(Sumber: Balai Arkeologi Maluku, 2017) 
hingga saat ini teori tentang jalur Islamisasi di Kepulauan Maluku (Provinsi Maluku dan Maluku Utara) masih terus dalam proses kajian. Beberapa pendapat yang mengemukakan teori masuknya Islam di wilayah ini diantaranya oleh Mailoa (1977), bahwa Islam berkembang di Maluku Utara diduga berasal dari Malaka, Kalimantan, atau Jawa. Prodjokusumo (1991), mengemukakan bahwa Banjar dan Giri atau Gresik cukup besar pengaruhnya dalam sosialisasi Islam di Maluku Utara, sebelum terjadi arus balik, yakni penyebaran Islam dari Maluku ke arah barat yakni Buton dan daerah lain di Sulawesi Selatan (Mailoa dan Prodjokusumo dalam Ambary, 1998: 153). Meski demikian, penting dicatat, Islam dianggap masuk ke wilayah Maluku pada sekitar abad 14, seperti yang terkandung dalam tradisi lisan yang menyebutkan Raja Ternate XII akrab dengan pedagang Islam. Selain itu Ambary (1998) juga mengemukakan kemungkinan lain bahwa Islam masuk melalui jalan Cina Selatan dan tidak melalui Selat Malaka. Pada abad 15, Ternate merupakan pusat kekuatan utama penghasil rempah-rempah. Diantara kerajaan besar lainnya, seperti Tidore, Jailolo, dan Bacan, Ternate menjadi pusat untuk memimpin aliansi empat kerjaan tersebut (Ambary, 1998: 153-154).

Fakta-fakta arkeologis menjadi penting dikedepankan, di tengah banyaknya penulisan sejarah yang lebih menitik beratkan di wilayahwilayah yang dianggap sebagai pusat peradaban Islam. Padahal, dari fakta-fakta arkeologis, kita bisa menemukan informasi atau setidaknya melengkapi catatan-catatan sejarah. Fakta-fakta arkeologis dapat memberikan informasi berharga dalam konteks informasi sejarah Islamisasi di wilayah Kepulauan Maluku, yang dapat dianggap sebagai fakta sejarah Islam yang paling fenomenal di wilayah Nusantara. Wilayah Kepulauan Maluku dapat dianggap sebagai wilayah dengan basis Islam yang kuat, dengan tumbuhnya empat Kesultanan, yang mengorganisir gerak dan laju Islamisasi di seluruh wilayah Nusantara bagian timur, meliputi daratan Pulau Sulawesi dan Papua. Pasang surut kekuasaan empat kerajaan tersebut juga turut berpengaruh terhadap perkembangan Islamisasi di wilayah-wilayah lainnya. Eskalasi penyebaran Islam ini, menjadi bagian integral dengan agenda perluasan jaringan niaga dan kekuasaan (Handoko, 2013).

Penelitian arkeologi dalam konteks studi sejarah Islam menurut Azyumardi Azra (2009), terutama sebelum abad $15 \mathrm{M}$, sangat membutuhkan dukungan data arkeologi untuk mengungkap fakta tentang kehidupan manusia pada masa lalu, terutama karena informasi sejarah bersumber dari sumber benda budaya atau artefak, yang antara lain dapat diperoleh melalui ekskavasi (Azra, 2009; Tjandrasasmitha, 2009: 109). Lokasi penelitian diarahkan di wilayah-wilayah kekuasaan Ternate, yakni di pesisir utara Halmahera Barat. Penentuan lokasi penelitian ini merujuk data pustaka sebelumnya tentang wilayah-wilayah ekspansi kekuasaan Ternate. Dalam konteks ini, penelitian di wilayah pesisir utara Kabupaten Halmahera Barat, yakni di wilayah bekas Kerajaan Loloda, sebagaimana yang tetulis dalam catatan sejarah. Selain itu, penelitian akan dikembangkan dari hasil wawancara. Penelitian arkeologi ini adalah untuk menelusuri dan menemukan bukti-bukti sejarah Kerajaan Loloda dan perkembangan Islam. Berdasarkan sumber sejarah yang terbatas, wilayah penelitian di Loloda adalah wilayah yang diasumsikan memiliki potensi dan strategis sebagai wilayah penyangga baik politik maupun ekonomi Kesultanan Ternate.

Permasalahan penelitian dalam konteks ini adalah menyangkut aspek kesejarahan Kerajaan Loloda yang selama ini masih terbatas, dan tanpa dukungan bukti arkeologis, sehingga bukti keberadaan Kerajaan Loloda juga belum diketahui. Selain itu menyangkut perkembangan Islam di Kerajaan Loloda juga belum diperoleh bukti material, sehingga catatan sejarah yang ada masih membutuhkan penjelasan secara arkeologis. Berdasarkan hal tersebut, maka diajukanlah pertanyaan penelitian sebagai berikut: Pertama, bagaimana konteks kesejarahan Kerajaan Loloda, terutama pada masa tumbuh kembangnya peradaban Islam? Kedua, bagaimana bukti-bukti arkeologi di wilayah situs Kerajaan Loloda menyangkut perkembangan Kerajaan Loloda dan perkembangan Islam?

Oleh karena itu, penelitian ini bertujuan untuk: Pertama, menjelaskan konteks sejarah Kerajaan Loloda dan perkembangan Islam sebagai wilayah kekuasaan Islam yang penting pada masa lampau. Dalam kerangka rekonstruksi sejarah kebudayaan, maka tujuan ini meliputi penjelasan tentang bagaimana perkembangan awal Islam dan perkembangan agenda Islamisasi itu sendiri berdasarkan data arkeologi yang ditemukan maupun berdasakan analogi data sejarah. Kedua, mengidentifikasi peninggalan 
arkeologi yang dapat memperlihatkan atau memberi gambaran mengenai keberadaan Kerajaan Loloda dan Agama Islam di wilayah ini. Berdasarkan tujuan penelitian, maka aspek perkembangan sejarah Loloda dan perkembangan Islam, dapat dicapai melalui kajian literatur, antara lain sumber-sumber pustaka tentang sejarah Loloda, cerita rakyat, toponim ataupun dokumen lainnya. Sementara untuk menjelaskan tentang fakta arkeologi untuk melihat bukti-bukti keberadaan Kerajaan Loloda dan pengaruh Islam, dapat dilakukan melalui kajian arkeologi, antara lain baik melalui survei, deskripsi, dan identifikasi temuan, maupun melalui pemetaan arkeologi.

\section{METODE}

Penelitian ini didahului melalui studi kepustakaan dengan mengumpulkan berbagai literatur tentang sejarah Kerajaan Loloda dan juga sejarah tentang perkembangan agama Islam. Pada tahap pengumpulan data sejarah, juga dilakukan wawancara terbuka dengan informan-infoman kunci unuk mengetahui berbagai informasi sejarah permukiman dan perkembangan wilayah, toponim-toponim kuno dan sebagainya. Sementara itu, untuk melacak bukti-bukti arkeologi tentang perkembangan Kerajaan Loloda dan agama Islam yang berkembang di wilayah itu, maka dilakukan penelitian arkeologi, yaitu melalui survei arkeologi untuk mengumpulkan data dan selanjutnya melakukan deskripsi temuan dan analisis terhadap data arkeologi yang ditemukan baik artefak, fitur, maupun analisis yang menyangkut hubungan antar artefak, maupun hubungan antara artefak dan sebarannya dalam ruang, termasuk didalamnya melakukan pemetaan dan analisis ruang untuk memperoleh penjelasan tentang aspek keruangan situs.

Metode survei permukaan dilakukan mengingat dalam tahap ini masih terbatas eksplorasi awal, sehingga melakukan survei dengan teliti diharapkan dapat menjangkau data yang diperlukan. Data yang dimaksud meliputi data artefak, fitur, dan kondisi lingkungan situs. Hal yang penting sebelum dilakukan survei adalah menyiapkan peta dasar atau peta topografi khususnya wilayah Pulau Halmahera dan sekitarnya. Survei dan observasi dilakukan di wilayah-wilayah yang menjadi bagian dari Kerajaan Loloda, yang informasinya diperoleh baik dari studi pustaka maupun wawancara.
Menurut Schiffer (1978), survei arkeologi merupakan penerapan seperangkat teknik memvariasikan probabilitas temuan arkeologi untuk memperkirakan parameter rekaman arkeologi di kawasan tertentu. Sementara itu, rekaman arkeologi didefinisikan sebagai distribusi artefak di atas permukaan tanah dengan karakteristik kepadatan yang sangat bervariasi. Lokasi ditemukannya kepadatan artefak, biasanya menjadi fokus lokasi survei. Oleh karenanya, desain survei mencakup distribusi artefak dengan kepadatan tinggi maupun kepadatan rendah. Pendekatan parameter situs melalui perbandingan kepadatan atau frekuensi temuan di lokasi survei, termasuk asosiasi situs atau artefak pada tipe lingkungan mikro, sesuai target yang ditentukan oleh masalah yang hendak diteliti (Schiffer, 1978: 2-3).

Dengan demikian, penelitian ini menggunakan survei arkeologi untuk melihat kepadatan temuan pada situs yang diduga sebagai bekas pusat Kedaton Loloda. Parameter tentang kepadatan temuan dan asosiasi antar artefak, antara artefak dan situs serta lingkungannya digunakan untuk mendeskripsikan, mengidentifikasi, dan menjelaskan bukti-bukti arkeologi sebagai petunjuk tentang keberadaan Kerajaan Loloda dan perkembangannya.

\section{HASIL DAN PEMBAHASAN \\ Konteks Sejarah Kerajaan Loloda}

Sejarah Maluku identik dengan sejarah kerajaan-kerajaan yang ada di daerah ini. Kenyataan historis menunjukkan bahwa di kawasan ini terdapat lebih dari 4 (empat) kerajaan. Empat kerajaan yang disebut dalam berbagai mitos dan legenda secara kronologis adalah Jailolo, Ternate, Tidore, dan Bacan memang merupakan kerajaan-kerajaan besar yang berpengaruh dan telah eksis sejak paruh pertama abad 13. Disamping itu, ada beberapa kerajaan kecil lainnya, seperti Loloda, Moro, dan Obi yang tidak begitu berpengaruh lantaran didominasi kerajaan-kerajaan besar, tetapi telah menghiasi lembar sejarah Maluku dan pantas dicatat (Amal, 2010: 6-7).

Penguasa kerajaan-kerajaan di Maluku ini disebut Kolano (dari bahasa Jawa Kelana) atau raja, dan setelah memeluk agama Islam sebutan kolano diubah menjadi Sultan. Diantara empat kerajaan besar tersebut, hanya Ternate dan Tidore yang mempunyai posisi penting dalam situasi politik, ekonomi, maupun militer. Keduanya 
mempunyai pandangan politik yang hampir sama yaitu ekspansionis, dan karenanya mempunyai kekuatan militer yang relatif hampir berimbang (Amal, 2010: 6).

Dalam politik ekspansionismenya, Kerajaan Ternate menanamkan pengaruh dan kontrolnya atas Ambon dan bagian barat pulaupulau Seram. Pada abad 16, dominasi Ternate akhirnya membentang dari Mindanao di utara hingga Flores di selatan, dari Sulawesi Utara (Manado, Gorontalo, dan kepulauan Sangir Talaud) hingga pantai timur Sulawesi Tengah (Kayeli, Tobungku, Banggai), dari pantai timur Sulawesi Selatan (Buton) hingga Seram Barat dan Banda. Kerajaan ini juga mulai menguasai wilayah Kerajaan Jailolo, Loloda, dan Moro, yang berakhir dengan lenyapnya kerajaan-kerajaan tersebut dan menjadi bagian integral Kerajaan Ternate. Pada pertengahan abad 16, puncak kedigdayaan Ternate tercapai dimasa pemerintahan Sultan Khairun (1535-1545) dan dari 1546-1570 serta Sultan Babullah (15701583). Ketiga kerajaan kecil lainnya tidak mempunyai peranan baik politik, ekonomi, maupuan militer yang relevan. Kerajaan Obi diambil alih oleh Bacan, sementara Moro dan Loloda di Halmahera Utara oleh Babullah digabungkan dengan Ternate. 1). Jailolo: Jiko ma-kolano, "penguasa teluk. 2). Tidore: Kie makolano, "penguasa gunung." 3). Ternate: Kolano Maluku, "penguasa Maluku." 4). Bacan: dehe makolano, "penguasa tanjung." Disamping sebutan untuk empat kerajaan tersebut, kerajaan Loloda juga disebut sebagai Ngara ma-beno, "tembok pintu gerbang," karena letaknya paling utara yang menjadi pintu masuk ke kerajaan-kerajaan lain (Andaya, 1993: 51; 2015: 44; Amal, 2010: 14).

Dalam urutan berdirinya kerajaan-kerajaan Maluku, Jailolo dipandang sebagai kerajaan tertua. Walaupun diakui sebagai kerajaan tertua oleh kerajaan-kerajaan Maluku lainnya, tidak dapat dipastikan kapan kerajaan ini didirikan. Hal yang dapat dicatat hanyalah peristiwa kesejarahan bahwa pada masa awal ada seorang Raja perempuannya yang kawin dengan Raja Loloda, sebuah kerajaan di bagian utara Pulau Halmahera yang mungkin merupakan kerajaan yang lebih tua dari Jailolo. Menurut cerita rakyat di daerah ini, perkawinan antara Ratu Jailolo dengan Raja Loloda merupakan perkawinan politik untuk memberikan akses kepada Jailolo untuk menguasai seluruh Halmahera. Politik Jailolo berhasil, sebab sebelum tahun 1250 , teritorial
Kerajaan Jailolo telah meliputi hampir seluruh Halmahera, termasuk Loloda. Sumber Nagarakartagama mengungkapkan bahwa ketika Jailolo terbentuk sebagai kerajaan, wilayahnya belum mencakup Halmahera Utara bagian barat, karena di sana terdapat Kerajaan Loloda. (Amal, 2010: 14) Loloda terlihat mampu melepaskan diri dari kekuasaan Jailolo. Ketika berlangsung pertemuan Moti pada abad 14, Raja Loloda berikhtiar untuk menghadiri pertemuan tersebut, tetapi terhalang oleh angin ribut, yang menyebabkannya mendarat di Dufa-dufa, Ternate (Amal, 2010: 15).

Berdasarkan kajian berbagai mitos yang berhasil direkam Portugis sekitar tahun 1544, Lapian menyimpulkan bahwa garis raja-raja Maluku berawal dari empat buah telur naga yang menetaskan tiga orang laki-laki dan seorang perempuan (Lapian, 1994: 12; Amal, 2010: 16). Dari tiga orang anak laki-laki itu, seorang menjadi Raja Bacan, yang lain menjadi Raja Papua, dan seorang lagi menjadi penguasa Butung dan Banggai, sementara yang perempuan menjadi permaisuri Raja Loloda. Berdasarkan versi ini, maka hanya terdapat dua kelompok Maluku Utara, Bacan sebagai yang tertua dan Loloda yang mewakili rakyat yang bertutur dengan bahasa Halmahera Utara (Amal, 2010: 15-16). Tidak ada penyebutan tentang Ternate, Tidore, dan Jailolo (Forrest, 1969: 31; Amal, 2010: 16). Dari teks ini kiranya dapat dianggap bahwa Loloda merupakan bagian dari wilayah kekuasaan Kerajaan Jailolo. Namun banyak sumber menyebut Loloda merupakan bagian dari kekuasaan Ternate (lihat Andaya, 2015: 111).

Kerajaan Loloda runtuh akibat perang Loloda tahun 1908. Faktor persaingan dengan pihak Kolonial dalam hal ini Portugis dan Belanda, menyebabkan kekuasaan Loloda semakin memudar dan hilang, dan dalam sebuah perjanjian yang disebut "Perjanjian Moti" tentang konfigurasi pemimpin-pemimpin kerajaan di Maluku, yaitu "Motir Staten Verbond," Kerajaan Loloda tidak dimasukkan dalam konfigurasi tersebut. (Amal, 2010, Mappanawang, 2012: 63;143; Mansyur, 2013: 65; Rahman, 2015: 208209). Raja Loloda adalah seorang yang miskin, karena daerahnya tidak ditumbuhi tanaman rempah-rempah. Ia tidak memiliki budak, dan permaisurinya, yang mempunyai hubungan dengan Kaicil Alam dari Jailolo (karena salah seorang Ratu Jailolo di masa awal pernah menikah dengan Raja Loloda), melakukan semua 
pekerjaan rumah seorang diri, seperti memasak makanan untuk Raja dan anak-anak, menyuci pakaian, dan mengambil kayu bakar di hutan. Apabila persediaan pangan menipis, sang Raja sendiri yang pergi menebang pohon sagu dan mengolahnya untuk memperoleh tepung sagu. Ia juga melaut memancing ikan, masuk hutan berburu, dan melakukan pekerjaan lain yang lazim dilakukan rakyat biasa (Andaya, 1993: 51, 93, dan 232; Andaya, 2015: 111; Amal, 2010: 128).

Ibukota Kerajaan Loloda dihuni pemukim Muslim, dan orang-orang Alifuru mendiami daerah pedalaman sekitar beberapa kilometer dari ibukota. Kerajaan Loloda hanya mempunyai 16 tenaga tempur laki-laki dari golongan Islam, dan sekitar 60 tenaga tempur Alifuru. Walaupun demikian, karena warisan historis, Loloda selalu menempati tempat khusus dalam upacara para Raja Maluku dan berhak menyandang gelar Kolano. Karena berasal dari keturunan telur naga, Raja Loloda memperoleh kedudukan dan martabat yang setara dengan raja-raja Maluku yang berasal dari kerajaan-kerajaan besar seperti Ternate, Tidore, Bacan, dan Jailolo. Gubernur Maluku, Robertus Padtbrugge (1677-1682), dalam memori serah terima jabatan kepada penggantinya, Jacob Lobs (1682-1686), mengingatkan sebutan yang terkenal bagi kerajaan-kerajaan di Maluku sebagai berikut: Loloda, ngara ma-beno (dinding pintu), Jailolo, jiko ma-kolano (penguasa teluk), Tidore, kie makolano (penguasa pegunungan), Ternate, kolano Maluku (penguasa Maluku), Bacan, dehemakolano (penguasa daerah ujung) (Andaya, 1993: 51, 93, dan 232; Andaya, 2015: 44, 111-112; Amal, 2010: 128). Makna sebutan tersebut menunjukkan bahwa dalam deretan kerajaankerajaan Maluku, Loloda termasuk salah satu diantaranya. Kerajaan Loloda adalah bagian tak terpisahkan dari kerajaan-kerajaan besar seperti Ternate, Tidore, Bacan, dan Jailolo. Tetapi, tentu saja, pengaruhnya tidak begitu signifikan dalam percaturan politik Maluku. Sebagai ngara mabeno, Kerajaan Loloda yang terletak di bagian utara Halmahera, menjadi "pintu masuk" ke kerajaan-kerajaan Maluku. Sedangkan Bacan, sebagai daerah paling ujung diselatan, merupakan pintu keluarnya.

Ketika bangsa Eropa tiba di Maluku pada permulaan abad 16, Kerajaan Loloda sudah tidak berperan dan tidak berpengaruh lagi lantaran dianeksasi Ternate. Walaupun demikian, hingga
1662, kerajaan yang berpenduduk sekitar 200 jiwa ini, sebagiannya adalah orang-orang Galela, masih dibiarkan Ternate berfungsi di bawah kekuasaannya, dan Raja Loloda masih diperkenankan menggunakan gelar kolano. Demikian pula dalam perjuangan Nuku melawan Belanda, barisan penasehat yang diangkatnya terdiri dari lima orang, masing-masing dua dari Maba, Kimalaha Galela, seorang dari Mareku, dan Imam Loloda. Ketika Ternate di bawah kendali Sultan Hamzah (1627-1648), Kerajaan Loloda praktis tenggelam. Pada 1628, atas perintah Hamzah, sejumlah penduduk Loloda dipindahkan ke Jailolo, setelah banyak penduduk Jailolo meninggalkan negerinya sebagai protes atas dilikuidasinya kerajaan mereka oleh Ternate (Amal, 2010: 128).

Loloda adalah salah satu wilayah yang menjadi bagian dari kepulauan rempah-rempah (the spices islands). Meski demikian, namanya tidak sepopuler empat kerajaan utama lainnya di kawasan ini yaitu: Ternate, Tidore, Bacan (Makian), dan Jailolo (Moti). Menurut letak geografisnya kini, Loloda berada di Pulau Halmahera di bagian utara dan Barat. Loloda secara umum terbagi atas dua bagian, yaitu Loloda Utara di Halmahera Utara (Halut) dan Loloda Selatan di Halmahera Barat (Halbar). Halmahera adalah pulau terbesar di Propinsi Maluku Utara. Wilayah dan penduduk Loloda secara administratif berada dan tersebar di Kabupaten Halmahera Utara dan Kabupaten Halmahera Barat. Tipologi geografis Loloda terdiri dari Loloda Daratan, Loloda Kepulauan, Loloda Teluk, dan Loloda Pegunungan. Saat ini, wilayah kerajaan Loloda diperkirakan berada di wilayah Kecamatan Loloda, Kabupaten Halmahera Barat, Kecamatan Loloda Utara dan Loloda Kepulauan yang termasuk wilayah administratif Kabupaten Halmahera Utara.

Melalui catatan-catatan sejarah yang telah diuraikan, maka penelitian arkeologi yang dimaksudkan adalah untuk menemukan buktibukti budaya fisik yang dapat mengonfirmasi catatan sejarah tersebut. Dalam konteks ini, maka penelitian arkeologi dimaksudkan untuk memberikan bukti arkeologi jejak sejarah Kerajaan Loloda. Untuk melengkapi catatan sejarah yang sudah ada, penelitian arkeologi diharapkan dapat meghadirkan fakta-fakta arkeologis untuk mengungkapkan berbagai isi budaya, dari wilayah-wilayah yang minim publikasi atau mungkin terpinggirkan oleh 
sejarah, terutama sekali dalam konteks peradaban Islam, termasuk Kerajaan Loloda.

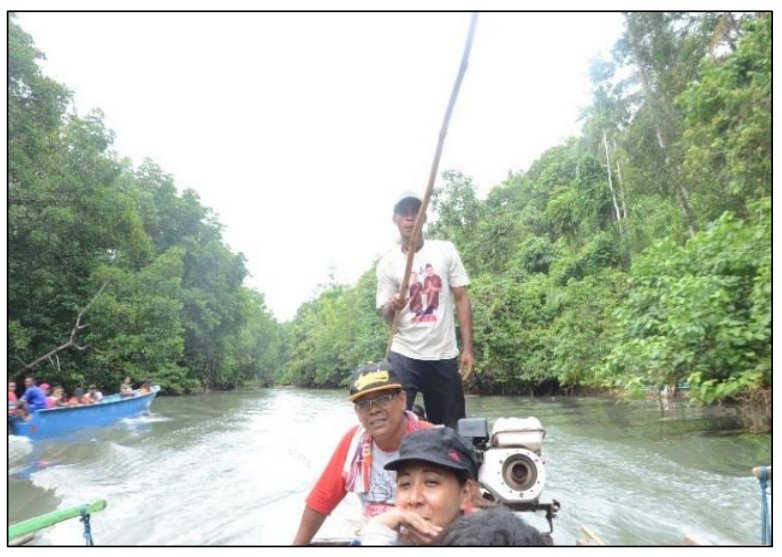

Gambar 2. Perjalanan tim penelitian arkeologi menelusuri Sungai Loloda untuk mencapai lokasi situs

Soasio Lama, di tepi sungai yang tercatat dalam sumber sejarah, banyak hidup buaya muara. (Sumber: Balai Arkeologi Maluku, 2017)

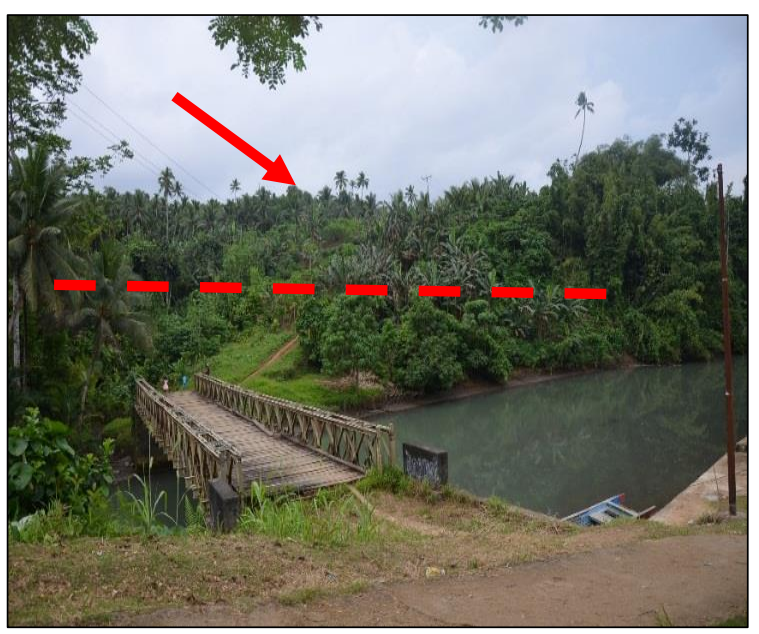

Gambar 3. Wilayah lingkungan Situs Soa Sio Lama, sebagai pusat kerajaan Loloda berada di tepi Sungai Loloda, lokasi situs adalah yang ditandai tanda panah dan garis putuh-putus.

(Sumber: Balai Arkeologi Maluku, 2017)

Berdasarkan wawancara dengan penduduk lokal saat ini, semakin menegaskan informasi bahwa Kerajaan Loloda pada masa lampau terletak di tepi Sungai Soa Sio atau sering dikenal juga sebagai Sungai Loloda. Pada masa kejatuhannya, lokasi tersebut ditinggalkan kosong begitu saja oleh penduduknya yang kemudian menyebar dan menempati tempat-tempat baru, baik di sepanjang pesisir pantai Loloda utara ataupun Loloda kepulauan. Banyak ungkapan yang kemudian muncul mengenai Loloda sejauh ini, yaitu Loloda diindikasikan sebagai kata atau konsep yang terabaikan, tersingkirkan, hilang, dan terlupakan dalam sejarah Lokal Maluku Utara dan sejarah nasional Indonesia. Karya-karya tulis mengenai perjalanan sejarah Loloda sejauh ini masih sangat sulit ditemukan. Oleh karena itu, Loloda tidak banyak diketahui dan karenanya jarang disebutkan.

\section{Pusat Kerajaan dan Bukti Arkeologi di DAS Loloda}

Hasil penelitian arkeologi terkini untuk melacak jejak Kerajaan Loloda di bagian utara Halmahera Barat, menemukan bukti-bukti bahwa Kerajaan Loloda sesungguhnya adalah kerajaan Islam di wilayah Daerah Aliran Sungai (DAS) Soa Sio, Loloda, Halmahera Barat. Jejak arkeologi di permukiman di tepian Sungai Loloda tersebut dapat mengonfirmasi catatan sejarah Kerajaan Loloda sebelumnya. Lokasi survei pada $\pm 100-500$ meter di bagian Barat Laut dari Desa Bakun. Pada areal dengan jarak tersebut merupakan lokasi permukiman, berdasarkan bukti-bukti yang ditemukan di permukaan tanah. Pada bagian utara - timur terdapat aliran Sungai Loloda, atau Sungai Soa Sio, ada pula yang menyebut Sungai Salu, merujuk Desa Salu yang terdekat di tepi sungai, serta beberapa sungai musiman yang merupakan batas sebaran temuan arkeologis. Lokasi tersebut merupakan hutan, ladang dan sebagian besar adalah lahan perkebunan masyarakat dengan bentuk topografi yang relatif datar dengan ketinggian 20-40 meter di atas permukaan laut.

Jarak terdekat sungai dari situs adalah sekitar 100-150 m, yakni di sebelah timur situs. Survei arkeologi yang dilakukan berhasil mendata beberapa jenis temuan arkeologis yaitu struktur kedaton, masjid tua (toponim), batu meja, makam, ake tidore, serta beberapa titik konsentrasi keramik. Secara umum, hampir keseluruhan temuan tersebut terkonsentrasi di sekitar struktur kedaton kecuali toponim ake tidore dan kompleks makam Islam yang berada \pm 400 meter arah barat laut dari struktur kedaton (lihat gambar 4). Struktur kedaton terletak di bagian timur dari sebaran temuan, $\pm 50-100$ meter bagian utara, timur, selatan terdapat lima titik konsentrasi keramik (tembikar, porselin, stoneware). Temuan batu meja atau dolmen (batu Wudhu), makam keramat (Jere), masjid tua (toponim), dan makam 


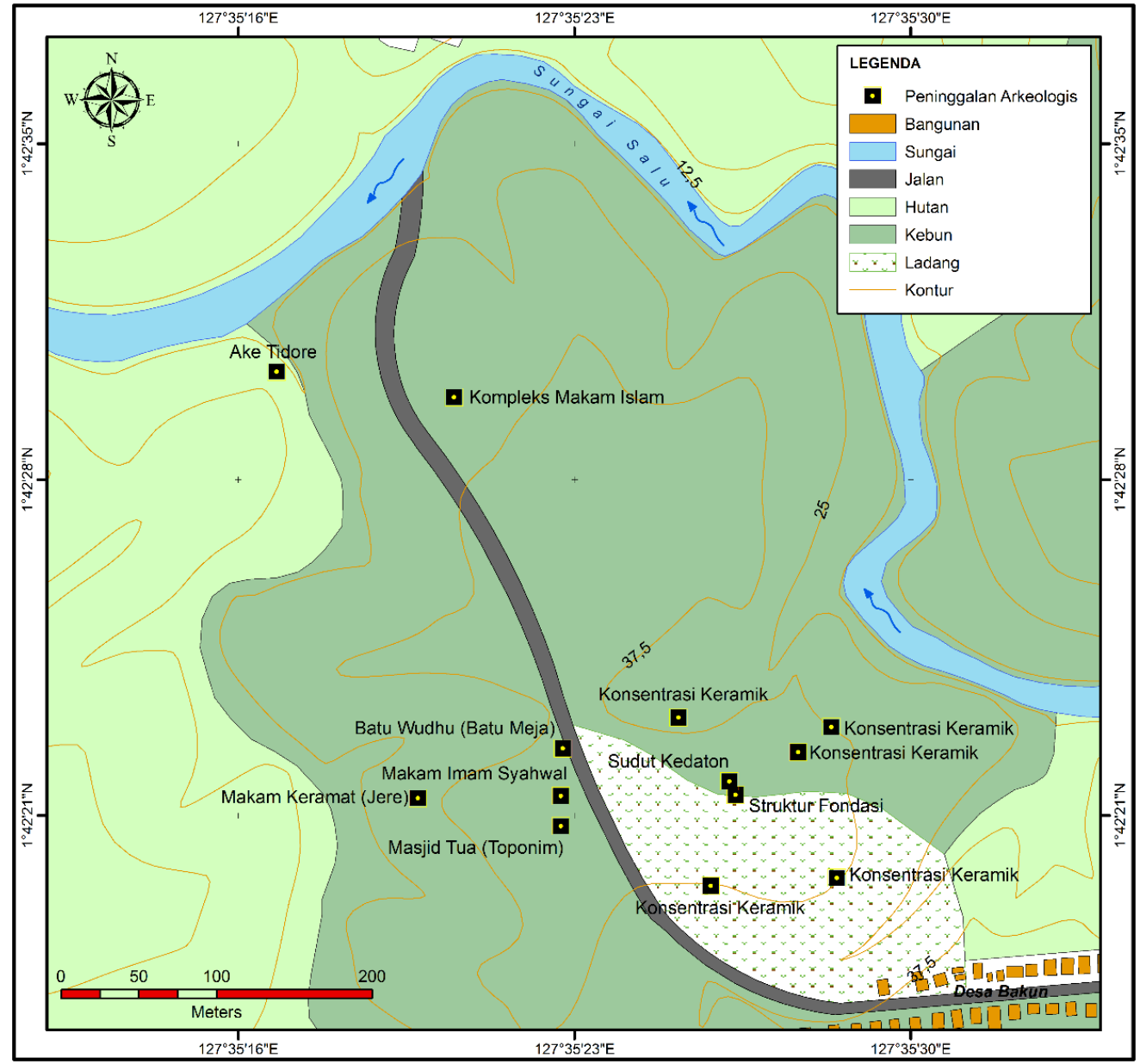

Gambar 4. Peta sebaran temuan arkeologi, yang memperlihatkan keletakan kedaton yang berasosiasi dengan sebaran artefaktual, fitur dan toponim di sekitar fitur bekas kedaton.

(Sumber: Balai Arkeologi Maluku, 2017)

Imam Syawal berada $\pm 100-200$ di bagian barat dari struktur kedaton, lalu toponim ake tidore dan kompleks makam Islam berada \pm 400 meter di bagian baratlaut dari struktur kedaton.

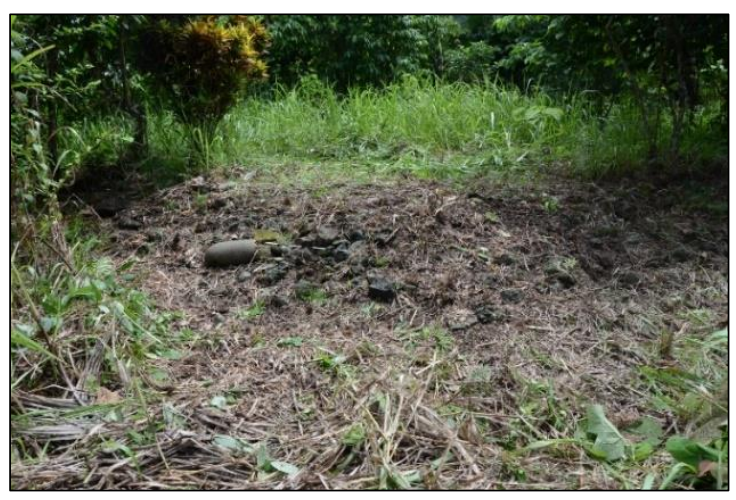

Gambar 5. Jejak-jejak arkeologi berupa susunan batu dan tanah yang ditinggikan, diidentifikasi sebagai lokasi bekas kedaton di situs Soasio Lama, di tepi Sungai Loloda

(Sumber: Balai Arkeologi Maluku, 2017)

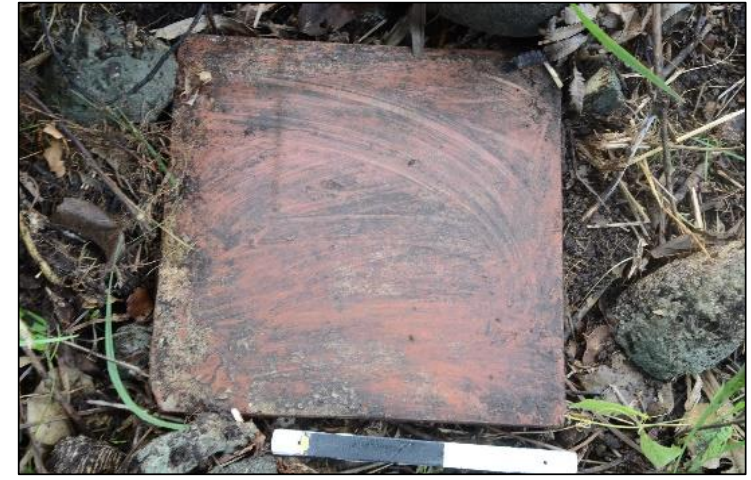

Gambar 6. Sisa-sisa lantai bangunan kedaton, terbuat dari bata merah, menunjukkan ciri bangunan kolonial pada umumnya

(Sumber: Balai Arkeologi Maluku, 2017)

Sejauh hasil penelitian arkeologi di lapangan, situs kampung tua Soa Sio, di tepi Sungai Loloda, menjelaskan bahwa Kerajaan Loloda, selain sebagai kerajaan pedalaman, juga 
kerajaan pesisir. Geografis pantai, laut dan sungai saling berintegrasi sebagai karakter khas lingkungan Kerajaan Loloda. Hasil survei menunjukkan bahwa posisi Kerajaan Loloda sangat strategis menghubungkan wilayah pesisir dan pedalaman.
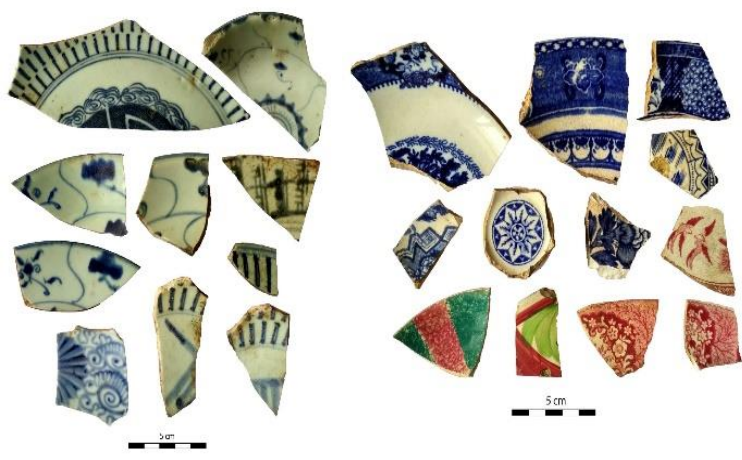

Gambar 7. Temuan keramik Cina (kiri) dan keramik Eropa (kanan) dari abad 19-20

(Sumber: Balai Arkeologi Maluku, 2017)

Di lokasi yang disebut Kampung Lama Soa Sio, ditemukan data-data arkeologi yang mendukung bahwa lokasi tersebut merupakan situs permukiman. Data utama dari lokasi ini adalah ditemukannya struktur bangunan, yang hanya menyisakan lansekap berupa permukaan tanah yang rata dan tampak ditinggikan dari permukaan tanah lainnya, dan juga susunan batu sebagai dasar bangunan. Berdasarkan susunan batu dan bentuk lansekap tanah yang ditinggikan, dapat diidentifikasi bentuk bangunan pada awal berdirinya, yakni persegi panjang dengan ukuran $12.5 \mathrm{~m} \mathrm{x} \mathrm{10m,} \mathrm{dengan} \mathrm{penambahan} \mathrm{ruang,} \mathrm{yang}$ berukuran $3 \mathrm{~m} \times 2 \mathrm{~m}$, pada bagian dinding timur sebelah utara. Kemungkinan merupakan sisa-sisa ruang dapur pada awal berdirinya bangunan tersebut. Melihat bentuk dan dimensi bangunan, tampaknya pintu bangunan menghadap ke barat. Pada bagian pintu di sebelah barat, masih ditemukan bekas lantai yang terbuat dari bata merah, berukuran $25 \mathrm{~cm} .{ }^{2}$ Hal ini mencirikan bangunan kolonial pada umumnya. Melihat posisi keletakkannya yang dikelilingi oleh sebaran artefak seperti keramik, tembikar dan fitur lainnya seperti makam kuno, toponim masjid kuno, kemungkinan struktur tersebut merupakan sisasisa bangunan kedaton. Loloda tampaknya dibangun pada masa pendudukan kolonial. Selain sisa bangunan berupa susunan batu, juga ditemukan konsentrasi sebaran keramik dan tembikar di permukaan tanah di sekitar areal bangunan kedaton. Berdasarkan sebarannya, tampak sebaran artefak yang terpusat di areal ditemukannya sisa-sisa struktur bangunan yang diindikasikan sebagai bekas Kedaton Loloda.

Loloda merupakan kerajaan yang menganut Islam sejak abad 17, kerajaan itu berpusat di Negeri Soa Sio, di tepi Sungai Loloda. Menurut tradisi tutur, lima kerajaan Islam Ternate, Tidore, Bacan, Jailolo dan Loloda dikenal dengan sebutan Moluko Kie Romtuha. Tampaknya pusat desa atau sebagai Ibukota Kerajaan Loloda adalah sebuah lokasi yang oleh penduduk sekarang disebut Soa Sio lama. Dari hasil survei, Soa Sio lama adalah sebuah lokasi yang cukup representratif sebagai tempat bermukim, sebuah dataran berbukit landai yang cukup luas, dan memungkinkan untuk menampung puluhan kepala keluarga atau ratusan jiwa penduduk. Wilayah itu memilik sumber air bersih yang cukup, disamping sungai Loloda yang bisa dimanfaatkan untuk kebutuhan sehari-hari. Namun tampaknya sumber air banyak diambil berasal dari cabang Sungai Loloda, dan di lokasi tersebut terdapat sumber mata air yang airnya sangat bersih. Penduduk menyebutnya sebagai Ake Tidore, sungai kecil dan sekaligus mata air yang airnya mengalir ke sungai Loloda (Soa Sio). Ake Tidore berada di sebelah lokasi permukiman Soa Sio Lama. Ake Tidore, tampaknya sebuah toponim, yang berhubungan dengan soal kedatangan seorang tokoh yang berasal dari Tidore dan kemudian meninggal di wilayah permukiman Soa Sio lama. Namun, tidak diperoleh keterangan yang lebih memadai untuk memberikan penjelasan tentang hubungannya dengan Kerajaan Loloda, mengingat catatancatatan sejarah tidak menyebut tentang hubungan Tidore dengan Loloda.

Hasil penelitian arkeologi ditemukan jejakjejak Kerajaan Loloda di tepi Sungai Soa Sio, penduduk menyebutkan sebagai Soa Sio lama, di lokasi itulah letak pusat kerajaan Loloda. Bukti pelacakan arkeologi tentang Kerajaan Loloda di situs Soa Sio Lama di DAS Sungai Soa Sio atau Sungai Loloda, yaitu berupa struktur, susunan batu yang diduga sebagai sisa-sisa kedaton Loloda, yang diperkuat oleh adanya ubin bata merah di lokasi tersebut. Selain itu, ditemukan pula sebaran keramik, baik dari masa Dinasti Ming (16--17), Qing (17-19), Eropa (19-20), bahkan ditemukan pula mangkuk Thailand Swangkhalok (16-17). Untuk melihat perbandingan kronologi keramik berdasarkan 
frekuensi pecahannya, maka dikumpulkan sebanyak 117 fragmen keramik yang mewakili keseluruhan konsentrasi temuan, yaitu 5 titik. Fragmen-fragmen keramik yang diidentifikasi berasal dari tiga periode yang berbeda, dan didominasi oleh jenis keramik yang berasal dari abad 19-20, sebanyak 86 keping (68\%), abad 16-17, sebanyak 37 buah (29\%) dan dari abad 18, 4 keping (3\%).

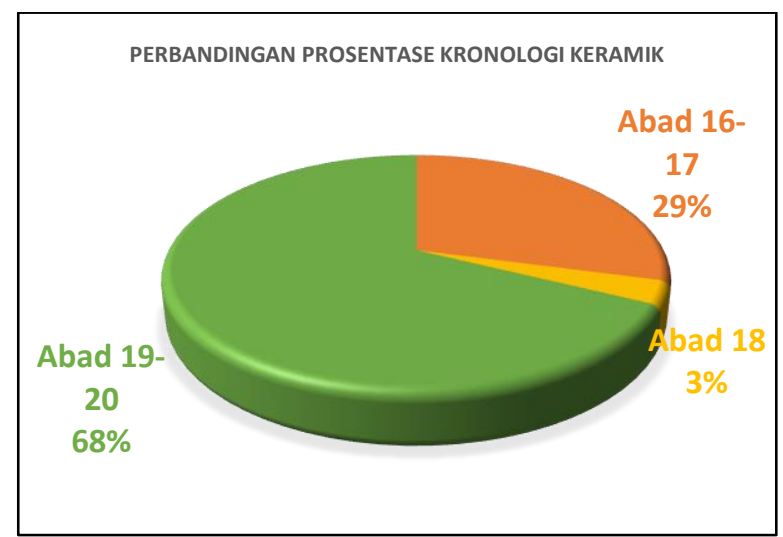

Gambar 8. Perbandingan prosentase kronologi keramik

(Sumber: Balai Arkeologi maluku, 2017)

Sementara itu jika, diurutkan berdasarkan kronologi keramik, berdasarkan interval waktu 50-100 tahun, maka diperoleh prosentasi frekuensi keramik dari masing-masing periode sebagai berikut:

Tabel. 1 Perbandingan Kronologi Berdasarkan Periode Keramik

\begin{tabular}{llr}
\hline Dinasti/Asal & Kronologi & Jumlah \\
\hline Qing dan Eropa (19-20) & $1850-1900$ & 76 \\
\hline Qing (19) & 1800 & 9 \\
\hline Qing (18) & 1700 & 3 \\
\hline Qing (17-18) & $1650-1700$ & 1 \\
\hline Qing (17) & 1600 & 12 \\
\hline Swankhalok & $1550-1600$ & 3 \\
\hline Ming & 1500 & 15 \\
\hline Sumber: Balai Arkeologi Maluku, 2017
\end{tabular}

Perbandingan frekuensi keramik menunjukkan, bahwa kronologi keramik mengalami pasang surut, namun berdasarkan kronologinya, dapat menjadi petunjuk bahwa sejak abad 16 sudah ada aktivitas niaga di Kerajaan Loloda. Bukti-bukti arkeologi yang ditunjukkan oleh kronologi relatif keramik, menunjukkan bahwa aktivitas niaga Kerajaan Loloda, sudah berkembang pada kisaran abad 16$17 \mathrm{M}$ dan berlanjut hingga abad 19-20.

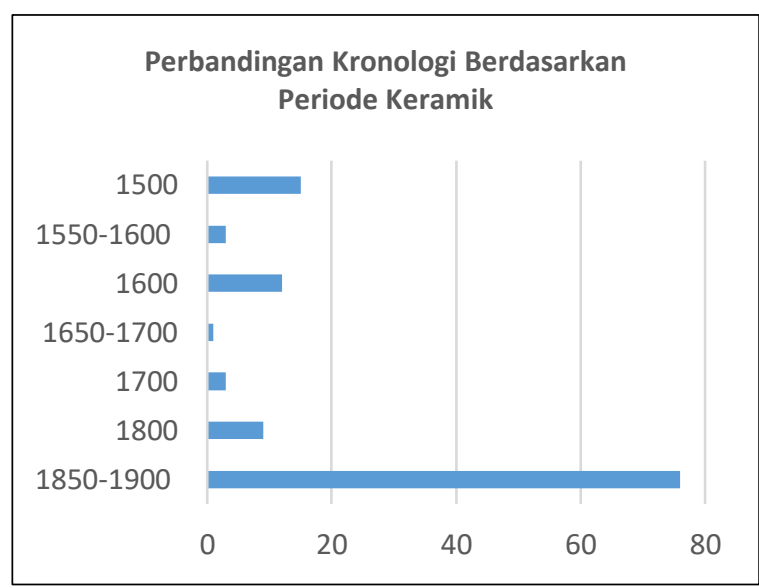

Gambar 9. Diagram batang perbandingan kronologi berdasarkan kronologi keramik

(Sumber: Balai Arkeologi Maluku, 2017)

Meskipun data arkeologi yang ditemukan masih minim, namun dari aspek lingkungan dan daya dukung lainnya, dapat diduga, lokasi itu sebagai bekas permukiman pusat Kerajaan Loloda sebagaimana yang dituliskan dalam teks sejarah dan tradisi tutur masyarakat setempat.

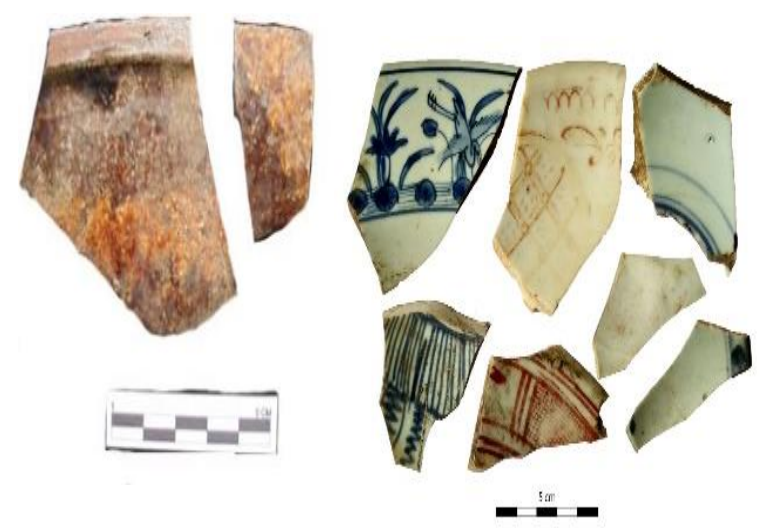

Gambar 10. Temuan keramik Thailand Sawankhalok (Abad 16-17) (kiri), Keramik Cina Abad 16 (kanan) (Sumber: Balai Arkeologi Maluku, 2017)

Data kronologi keramik mengonfirmasi adanya hubungan perdagangan Kerajaan Loloda dengan daerah-daerah luar, baik secara langsung maupun melalui pedagang perantara. Pada masa lampau, diperkirakan jalur pantai Loloda baik di sebelah barat maupun sebelah utara, merupakan jalur lintasan pelayaran dan niaga yang keluar masuk ke wilayah kerajaan ini. Di pesisir pantai 

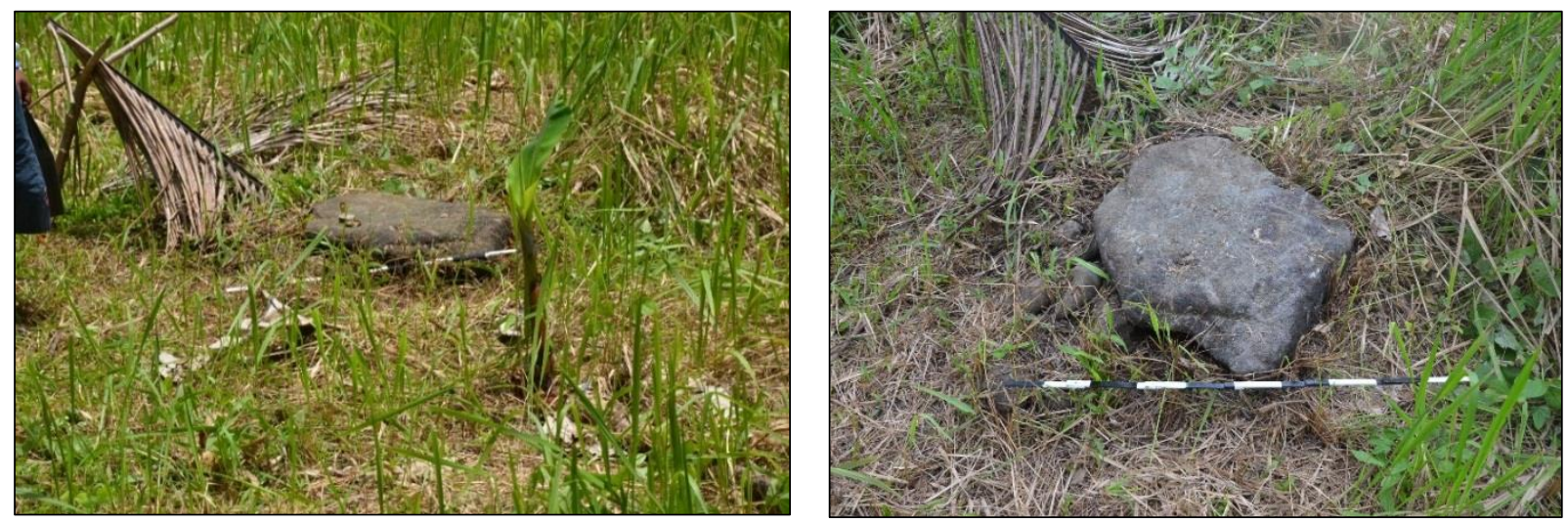

Gambar 11. Batu wudhu, dipercaya sebagai peninggalan alat kelengkapan masjid, sebagai alas kaki pada saat orang muslim Soasio Loloda mengambil air wudhu. Dari perspektif arkeologi batu wudhu itu adalah dolmen, alat batu masa tradisi megalitik (pra Islam) yang masih difungsikan oleh masyarakat saat berkembangnya Islam

(Sumber: Balai Arkeologi Maluku, 2017)

sebelah barat, berhubungan dengan Kerajaan Jailolo dan Ternate, sedangkan di sebelah utara berhubungan dengan wilayah Galela dan wilayah Halmahera Utara lainnya, yang dalam hal ini termasuk wilayah dari Kerajaan Moro. Sementara itu, muara dan sungai Loloda adalah pintu dan lintasan masuknya kapal-kapal dagang ke wilayah bagian dalam sungai, tempat Kerajaan Loloda berpusat.

Selain keramik, juga ditemukan sebaran tembikar, yang berasosiasi dengan keramik di lokasi yang sama. Menyangkut keberadaan tembikar, yang terkonsentrasi dan berasosiasi dengan keramik, hal ini menunjukkan bahwa tembikar dan keramik merupakan alat perkakas rumah tangga sehari-hari yang digunakan penduduk pada masa itu. Meskipun dalam survei ini frekuensi temuan tembikar lebih sedikit dibanding keramik, namun keberadaan tembikar kemungkinan juga berasal dari luar Loloda. Mengenai jalur distribusi atau perdagangan tembikar, wilayah perairan barat Pulau Halmahera merupakan jalur pelayaran distribusi barang di wilayah Maluku Utara. Menurut Mahirta (1996), aktivitas pelayaran dan perdagangan di wilayah Maluku Utara sudah terjalin sejak masa lampau, dalam konteks distribusi tembikar dari Pulau Mare. Setidaknya terdapat tiga jalur pelayaran dan perdagangan yang sudah terbentuk sejak masa lampau, yakni pelayaran sepanjang pantai barat Pulau Halmahera, sepanjang pulau Halmahera hingga Morotai, dan sepanjang kepala burung dan berputar di sepanjang Teluk Weda. Jika merujuk pada pendapat ini, maka dapat diduga, keberadaan tembikar di Kerajaan Loloda tidak menutup kemungkinan berasal dari Pulau Mare. (Mahirta, 1996a; Mahirta, 1996b: 124-131). Meski demikian, untuk hal ini belum dapat dipastikan, mengingat diperlukan analisis lebih mendalam untuk membandingkan ciri tembikar Mare dengan temuan di situs Loloda

Berdasarkan wawancara dengan penduduk, diperoleh informasi tentang toponim yang disebut Aha Kolano, yakni sebuah wilayah dusung (tanah perkebunan) milik Kolano Loloda, yang ditumbuhi oleh tanaman-tanaman pangan seperti sagu dan padi ladang, yang letaknya jauh dari situs permukiman Soa Sio Lama, Ibukota Kerajaan Loloda di tepi sungai. Meski demikian, informasi menyangkut toponim Aha Kolano, belum ditindak lanjuti melalui penelitian arkeologi, sehingga belum diperoleh data dan informasi secara faktual berdasarkan data arkeologi baik artefak, fitur dan lain-lain. Meski demikian, hasil survei arkeologi di DAS Loloda, ditemukan situs dengan dukungan sejumlah data arkeologi yang dapat mendukung keterangan sejarah, sebagaimana yang diuraikan sebelumnya.

Meskipun dalam catatan sejarah Kerajaan Loloda adalah sebuah kerajaan kecil yang dianggap miskin, namun catatan sejarah lainnya menyebut bahwa Loloda adalah pemasok kebutuhan pokok Kesultanan Ternate. Informasi ini perlu dikaji lebih lanjut, mengingat fakta di lapangan, bahwa Loloda hingga kini merupakan daerah yang kaya kopra, bahkan hingga kini, sagu dan tradisi pertanian padi ladang juga masih berlanjut meskipun untuk kebutuhan sendiri. Jejak arkeologi yang menunjukkan bahwa situs Soa Sio Lama pada masa lalu merupakan Ibukota Kerajaan Loloda, yaitu berdasarkan dari temuan 
struktur bekas kedaton, lokasi masjid kuno, makam kuno, dan sebaran keramik sebagaimana yang sudah disebutkan sebelumnya, tembikar, fragmen kaca atau botol produksi Eropa, dan uang koin.

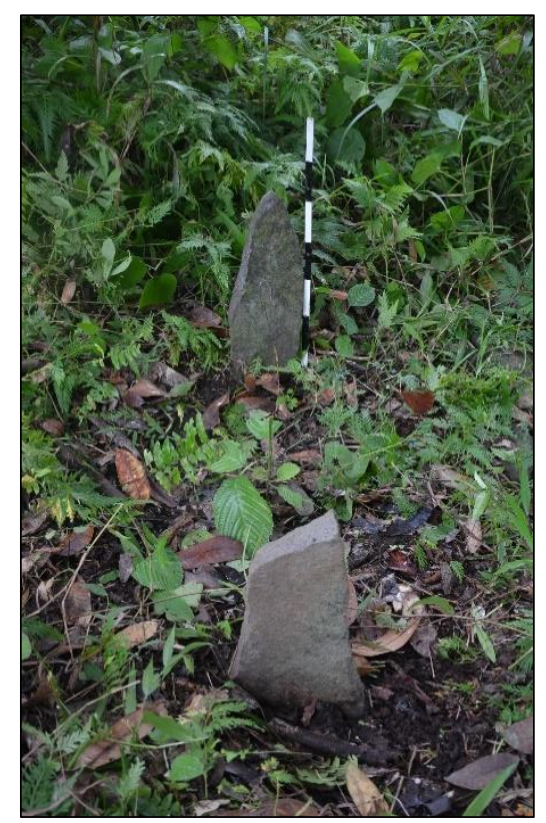

Gambar 12. Makam kuno di Loloda dengan ciri nisan batu (menhir berukuran kecil)

(Sumber: Balai Arkeologi Maluku, 2017)

Demikian pula, tentang peninggalan masjid kuno juga sudah tidak ada sisa-sisanya, kecuali lokasi yang dipercaya masyarakat sebagai bekas lokasi masjid, berupa areal tanah yang tampaknya ditinggikan dan permukaannya rata. Lokasi yang disebut sebagai toponim masjid tua berada pada jarak $114 \mathrm{~m}$ di sebelah barat dari struktur bekas kedaton (lihat Gambar 4). Kondisi arealnya pun sudah sulit dikenali, mengingat banyak tumbuhan perdu dan semak belukar yang rimbun dan menutupi lokasi. Pada bagian barat lokasi masjid, berjarak $50 \mathrm{~m}$ ditemukan sebuah batu pipih, yang sesungguhnya adalah dolmen, yakni batu berbentuk seperti meja yang digunakan untuk ritual tertentu pada masa sebelum berkembangnya agama Islam. Dolmen, tersebut adalah peninggalan pra Islam, namun menurut kepercayaan masyarakat setempat, dikenal sebagai Batu Wudhu, yakni batu yang digunakan sebagai alas pada saat menyucikan diri atau mengambil air wudhu, pada masa lampau.

Selain itu, di lokasi situs juga ditemukan beberapa makam kuno Islam, satu diantara makam tersebut adalah makam Imam Syawal, yang dipercaya sebagai imam pertama kerajaan
Loloda. Makam ini adalah makam kuno, dengan nisan berbentuk menhir, namun sekarang sudah diperbaharui, sehingga kehilangan nilai kekunoannya. Ciri makam kuno, dengan susunan jirat batu dan nisan menhir, merupakan ciri makam kuno yang umum di Maluku Utara. Masyarakat menyebutnya jere keramat. Ciri ini sesungguhnya merupakan bentuk adaptasi budaya pra Islam yang masih berlanjut meskipun masyarakat sudah mengenal Islam. Selain makam Imam Syawal, juga dijumpai makam-makam kuno lainnya, yang lokasinya terkonsentrasi dan tidak berada pada area yang sama dengan makam Imam Syawal. Lokasi konsentrasi makam, berada di sebelah utara Situs Kedaton Soa Sio, dan lebih dekat ke arah Sungai Loloda. Makam pada umumnya menunjukkan makam Islam dengan tipologi lokal, yakni tipologi pengaruh budaya pra Islam, dengan nisan menhir dan beberapa diantaranya sudah diperbaharui, sehingga tidak memperlihatkan ciri aslinya.

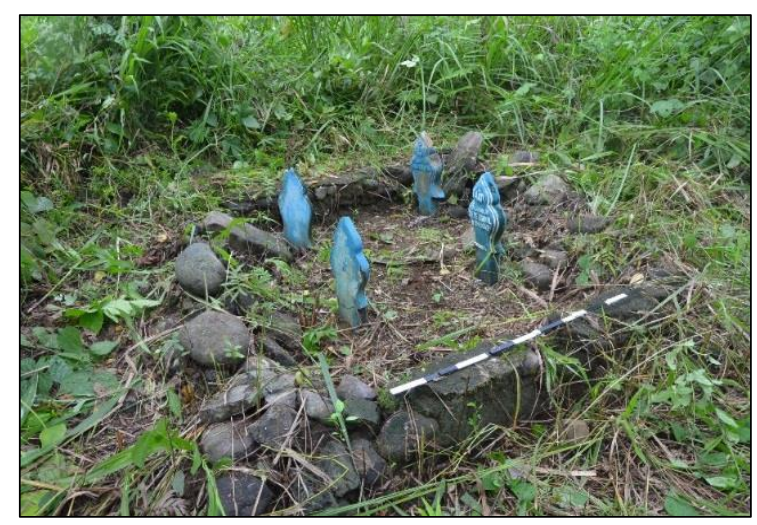

Gambar 13. Makam Imam Syawal di situs bekas pusat kerajaan Loloda. Dalam catatan sejarah Imam Syawal adalah imam pertama saat Loloda menjadi daerah distrik (masa penguasaan Belanda)

(Sumber: Balai Arkeologi, 2017)

Selain makam-makam Islam yang sudah disebutkan, juga ditemukan satu makam unik, yang berbeda dengan makam lainnya, yakni sebuah makam yang berorientasi timur-barat yang menunjukkan makam pra Islam. Kemungkinan yang dimakamkan adalah tokoh masyarakat asli (alifuru) yang belum beragama Islam. Ukuran makam yang sangat besar dengan nisan batu menhir dan berorientasi cenderung arah barat timur, berbeda dengan makam-makam Islam sebelumnya yang berorientasi utara-selatan. Ukuran makam, dengan jirat atau badan makam, mencapai 5,4 meter. Ukuran panjang makam, diukur berdasarkan keletakan nisan menhir di 
bagian barat dan timur. Keberadaan makam ini, memberikan penjelasan bahwa lokasi Soa Sio, merupakan sebuah kampung yang sudah dihuni sebelum munculnya komunitas muslim Loloda. Dalam catatan sejarah, disebutkan bahwa selain kampung muslim Soa Sio, juga terdapat kampung-kampung pedalaman, yang masih menganut agama suku.

Selain temuan fitur bekas kedaton dan masjid, maupun temuan artefaktual seperti yang disebutkan sebelumnya, temuan koin logam bertahun 1898 dan artefak botol-botol Belanda, serta keramik Eropa, dapat menjadi bahan interpretasi bahwa wilayah ini pada masa itu dikuasai oleh pihak Kolonial. Meski jumlah temuan koin yang minim atau hanya satu buah berdasarkan survei yang dilakukan, kemungkinan menunjukkan bahwa pada masa itu, alat tukar yang digunakan berupa uang Belanda, yang dapat pula diterjemahkan bahwa ekonomi kolonial menguasai wilayah itu. Meskipun demikian, dari bukti-bukti arkeologi yang masih minim, dapat mengonfirmasi informasi sejarah tentang keberadaan Kerajaan Loloda di masa lalu. Secara geografis, Loloda merupakan kerajaan pedalaman di Daerah Aliran Sungai (DAS) yang sangat terbuka berhubungan dengan wilayah lain melalui laut. Wilayah kerajaan luar yang paling dekat dan mudah berhubungan dengan Loloda adalah Jailolo di Halmahera Barat dan Galela di wilayah Halmahera Utara. Minimnya data arkeologi yang ditemukan dalam penelitian ini belum sebanding dengan catatan sejarah yang ada. Demikian pula, catatan sejarah yang ada masih minim dari penulisan sejarah yang utuh tentang Loloda. Penelitian ini masih sebatas menjangkau daerah Loloda yang diwakili situs Soa Sio Lama, yang dianggap sebagai pusat Kerajaan Loloda pada masa lampau. Masih perlu dikembangkan lagi survei-survei arkeologi di wilayah Loloda Utara dan Loloda Kepulauan untuk melihat sebaran data arkeologi, juga melihat sebaran budaya di wilayah Kerajaan Loloda pada masa lampau.

\section{Kerajaan Loloda dan Perkembangan Islam}

Kampung Muslim yang dimaksud van Fraassen adalah Soa-Sio, karena Soa-Sio yang dimaksud pada abad ini terletak di tepi Sungai Loloda. Pada Lokasi inilah, tim survei arkeologi menemukan jejak peninggalan arkeologi dari kerajaan Loloda. Jejak arkeologi berupa kedaton, masjid kuno, batu wudhu, dan makam-makam kuno berorientasi utara-selatan, salah satunya makam Imam Syawal, membuktikan bahwa lokasi situs merupakan daerah permukiman muslim. Hal ini dapat dikonfirmasi dengan catatan sejarah, yang menyebutkan bahwa di Soa Sio inilah, kediaman atau kedudukan Raja Loloda merupakan seorang muslim. Meskipun raja adalah seorang muslim, namun dalam sumbersumber Belanda tidak disebutkan eksistensi Penguasa Loloda dengan gelar Sultan. Sekalipun demikian, dalam pemahaman orang Loloda saat ini, mereka senantiasa memberi konotasi yang sama antara raja (kolano) dengan sultan (Sjah, 2005: 26; Rahman, 2015: 11). Dalam sejarah, tercatat pengaruh Islam dapat dilihat dari adanya permukiman muslim yakni Soa-Sio dan Bantoli di Ibukota Loloda. (de Clerk, 1890: 74; Rahman, 2015: 211).

Loloda adalah salah satu daerah pusat kekuatan politis yang melahirkan gelar kolano (raja) yang dibantu oleh Jougugu (Kapitan laut dan hukum), sebagaimana halnya fungsi politik yang serupa di Ternate. Faktanya ialah bahwa penguasa Loloda tertinggi bergelar kolano sebagaimana halnya gelar kolano sebelum digantikan dengan gelar Sultan bagi raja Ternate dan Tidore, namun kemudian Loloda dinyatakan terpisah. Pada abad 17, Loloda telah menjadi pusat Islam (Mappanawang, 2012: 63, 143). Tahun 1662 penduduk Loloda diperkirakan berjumlah 200 orang dan di tahun 1686 muslim Loloda berjumlah 16 orang (Andaya, 1993; 2015; Amal, 2010; Mappanawang, 2015). Sementara penduduk Alifuru berjumlah 60 orang. Pada 1911 sekitar 19 desa dengan jumlah penduduk 4000 jiwa beragama Islam, Kristen, dan Pagan. Pada tahun 1686 terdapat lima desa yang ditempati oleh orang-orang Alifuru (di luar desa-desa muslim utama), lima desa orang Alifuru itu adalah LoboLobo, ToboTobo, Kedi Togolami, dan Bakune, mereka semua berjumlah kira-kira 60 orang. Desa-desa Alifuru yang lain adalah, Baru, Bakun, Kedi, dan Laba (Mappanawang, 2015).

Pengaruh Islam terhadap sistem politik di Loloda membawa pengaruh terhadap penyebaran Islam di wilayah Loloda pada masa-masa berikutnya. Hal ini dapat dilihat dari data statistik 1917, bahwa jumlah penduduk Loloda yang telah beragama Islam sebanyak 1155 . Jumlah itu tersebar di kampung Soa-Sio (248), Tolofuo (330), Baja (56), ToboTobo (87), Fitako (119), Dedeta (149), Dama (103), dan Tate (63). Angka tersebut termasuk Kampung Pocao, karena data statistik tersebut hanya mencantumkan penduduk 
Pocao terdiri dari Islam dan Alifuru (kafir) (Baretta, 1917: 104-109 dalam Rahman, 2015: 214-215). Dengan adanya pengaruh Islam terhadap sistem politik di Loloda, menunjukkan adanya perubahan sosial dalam bidang kebudayaan. Perubahan sosial itu telah mempengaruhi transformasi politik di Loloda, menunjukkan adanya perubahan sosial dan kebudayaan. Perubahan sosial itu telah mempengaruhi transformasi politik di Loloda dari sistem kerajaan ke sistem distrik, namun peran Islam yang dilegitimasikan dalam sistem pemerintahan di Loloda (Bobato Soa Sio) yakni Soa Lebe tetap eksis. Dengan demikian, dapat dikatakan pengaruh Islam justru merupakan landasan dari sistem politik di Loloda.

Pada awal abad 20, pengaruh Islam terhadap sistem politik di Loloda juga terlihat, keadaan ini bisa dilihat dari catatan van Baarda pada 1904 yang berjudul "Het Loda'sch in Vergelijking met het Galela'sch Dialect op Halmaheira" (perbandingan dialek bahasa Loloda dengan Galala di Halmahera). Dalam catatan itu, disebutkan bahwa Kolano Loloda adalah seorang muslim dan di Ibukota Loloda dihuni orang Islam, karena terdapat mesjid dan ada seorang imam. Selain itu, di sana-sini juga ditemukan pedagang yang beragama Islam (Baarda, 1904; Rahman, 2015: 214). Dengan mengacu pada pengertian Soa Sio, baik sebagai permukiman muslim, pusat pemerintahan, maupun sebagai salah satu soa yang mengurusi masalah syari'ah Islam, maka dapat dikatakan bahwa Islam telah ditransformasikan ke dalam sistem politik Loloda. Hal ini dapat dilihat dari sistem kedudukan raja/kolano (kepala distrik) yang beragama Islam. Pusat pemerintahan berkedudukan di Negeri Soa Sio sebagai permukiman Muslim, dan ada suatu lembaga yang mengurus mengenai masalah Syari'ah Islam dalam Bobato Soa Sio yakni Soa Lebe. Dalam istilah lokal, lembaga yang menangani masalah Syari'ah Islam disebut Bobato Akhirat. Bobato ini dipimpin oleh seorang imam atau mufti. Dalam istilah lokal, mufti disebut juga dengan Jo Qalem atau Jo Lebe (Yusuf, 2005: 148; Rahman, 2015: 99).

Ketika kedudukan raja (kolano) dilikuidasi dan ditransformasikan dengan kedudukan sangaji oleh Pemerintah Hindia Belanda setelah Februari 1909, pengaruh Islam bisa dikatakan tetap menjadi bagian sistem politik Loloda. Dikatakan demikian karena sangaji yang ditempatkan di Loloda dipastikan seorang muslim, dan imam atau
Jo Lebe tetap berada di bawah sangaji untuk menjalankan syari'ah Islam. Pada perkembangan berikutnya, istilah imam atau Jo Lebe Loloda disebut sebagai imam Distrik Loloda. Adapun Imam Distrik pada saat itu bernama Imam Syawal (Mansyur, 2007: 65; Mansyur, 2013: 149).

Loloda, meskipun cerita tentang masuknya Islam tidak dimuat dalam berbagai catatan terutama hikayat, namun berdasarkan sumbersumber lisan dapat digambarkan bahwa masuknya Islam di Loloda dikaitkan dengan tokoh-tokoh legendaris yang memiliki kekuatan magis dan supranatural. Berdasarkan mitos kelahiran raja Loloda, bisa dikatakan bahwa Islam telah masuk Loloda. Hal ini terlihat dari nama Raja Loloda yang menggambarkan nama bercirikan Islam, yakni Usman dengan gelar Malamo (agung). Kehadiran Syekh Usman dari Irak itu, bisa menjelaskan tentang proses penyiaran Islam yang meliputi Ternate dan Halmahera muka termasuk Loloda dan Ibu (Mansyur, 2013: 142). Meskipun Islam telah masuk di Loloda, namun tidak dapat dijelaskan apakah Islam telah melembaga ke dalam struktur pemerintahan di Kerajaan Loloda pada abad 15 sebagaimana di Ternate. Pada abad ini (1486), Islam telah masuk ke dalam sistem politik di Ternate yang ditandai dengan adanya gelar Sultan untuk Raja Ternate. Adapun Raja Ternate yang pertama kali memakai gelar sultan adalah Zainal Abidin Sjah (Putuhena, 1983: 315). Di Loloda, Islam dapat dikatakan masuk ke dalam sistem politik setidak-tidaknya pada abad 17. Hal ini berdasarkan tulisan Chr. F. van Fraassen yang berjudul Types of Socio Political Structure in North-Halmahera History (1979). Menurutnya, pada abad 17, Loloda telah menjadi sebuah pusat Islam karena pada tahun 1686 kampung utama Loloda dan kediaman Kolano Loloda adalah kampung muslim di tepi Sungai Loloda, sehingga ia menyimpulkan bahwa Kolano Loloda adalah seorang muslim (van Fraassen, 1979: 115; Rahman, 2015: 211).

Berdasarkan silsilah pemimpin-pemimpin Loloda, yang sumbernya diperoleh dari masyarakat Loloda sekarang, menunjukkan nama-nama pemimpin Loloda dengan nama dan gelar yang identik dengan Islam. Dengan demikian, dapat dipastikan bahwa Loloda adalah sebuah Kerajaan Islam yang berkembang, sebagaimana catatan-catatan sejarah yang sudah ada sebelumnya. Catatan yang menarik pula adalah bahwa pada masa lalu, Loloda disebut sebagai wilayah vassal dari Ternate. Leirissa 
(1990) menyebut Loloda adalah salah satu wilayah di Halmahera yang menjadi pemasok kebutuhan pokok Ternate (Leirissa, 1990: 133).

Dalam soal Islamisasi, sebuah sumber menyebut, bahwa proses Islamisasi di Loloda berasal dari salah satu penganjur Islam, bernama Syekh Mansyur, yang menyiarkan Islam di Ternate dan Halmahera 'muka'. Halmahera 'muka' di sini bisa jadi adalah Loloda dan Ibu (Assegaf, 1974: 15; Rahman, 2015: 211). Menyangkut nama Syekh Mansyur, kiranya menarik jika dihubungkan dengan temuan makam kuno, yang dipercaya sebagai Makam Syekh Mansyur, yang konon berasal dari Baghdad. Makam kuno berada di situs pedalaman di wilayah Kao, Halmahera Utara (Tim Penelitian, 2014; Handoko, et al., 2016; Handoko, 2017: 106). Namun sumber lain, juga menyebut bahwa tokoh Syekh Mansyur, merupakan penyiar Islam yang mengajarkan Islam di wilayah Tidore (Tudoho, 2013). Tampaknya mengenai nama Syekh Mansyur, banyak diklaim sebagai penyiar Islam di berbagai tempat di Maluku Utara, antara lain Ternate, Loloda, Kao, dan juga Tidore. Kemungkinan nama Syekh Mansur berhubungan dengan perkembangan tradisi Islam sufi di wilayah-wilayah tersebut. Menyangkut toponim Ake Tidore di lokasi situs Soa Sio Lama di Ibukota Kerajaan Loloda merupakan informasi baru sebagai bahan interpretasi hubungan Loloda dan Tidore dalam soal syiar Islam.

\section{KESIMPULAN}

Penelitian arkeologi menemukan bahwa Kerajaan Loloda, adalah kerajaan di wilayah daerah aliran Sungai Loloda atau Soa Sio. Lokasinya adalah di situs yang disebut masyarakat sebagai Soa Sio Lama. Hasil survei arkeologi menemukan adanya indikasi permukiman, dan juga sebagai pusat kerajaan Loloda. Temuan struktur batu dan lansekap tanah rata yang ditinggikan, teridentifikasi sebagai bekas kedaton. Selain itu dukungan sebaran artefaktual yang terkonsentrasi di areal itu menguatkan bukti adanya aktivitas yang terpusat di lokasi tersebut. Selain itu, dari sebaran artefaktual dan daya dukung lingkungan dan sumber air, tampaknya lokasi situs menunjukkan situs permukiman yang cukup berkembang, setidaknya sejak abad 16-17. Dukungan kronologi keramik dari periode abad 16-17 menguatkan adanya aktivitas pertukaran dan perdagangan pada periode itu. Selanjutnya pada kurun waktu abad 19-20, wilayah tersebut dikuasai oleh kolonial Belanda. Bukti kronologi keramik yang dominan dari abad 19-20, terutama keramik Eropa menjadi indikasi kuat periode kolonialisasi di wilayah Loloda, selain dukungan catatan-catatan sejarah menyebut bahwa kerajaan Loloda sejak abad 19-20 runtuh akibat kalah dan dikuasai Eropa.

Berdasarkan tradisi tutur, sejak dikuasai kolonial, saat itu penduduk Soa Sio Lama berdiaspora ke wilayah atau ke daerah lain mencari daerah aman atau mencari penghidupan yang baru. Tradisi tutur juga menyebutkan bahwa penduduk Loloda sekarang, baik yang menempati desa-desa di wilayah kecamatan Loloda sekarang ataupun di wilayah Loloda Utara dan Loloda Kepulauan, asal muasalnya berasal dari kampung Soa Sio Lama, yang dulu merupakan pusat Kerajaan Loloda. Pada masa mendatang, diperlukan penelitian dan kajian yang lebih mendalam lagi, untuk mempelajari dinamika sosial, ekonomi dan agama masyarakat Kerajaan Loloda, yang berhubungan dengan kontak budaya masyarakat lokal Loloda dengan pihak kolonial, juga topik dan isu berkaitan dengan periode kontak dan perubahan masa Islam (pra kolonial) ke masa pendudukan kolonial. Metode ekskavasi dan analisis multidisiplin masih diperlukan untuk mengetahui berbagai perubahan sosial budaya sejak pra kolonial hingga berbagai bentuk perubahan setelah dalam penguasaan kolonial.

\section{Ucapan Terima Kasih}

Penulis mengucapkan terima kasih kepada banyak pihak atas hasil penelitian arkeologi ini. Terima kasih ditujukan kepada Godlief Arsthen P., yang banyak membantu menyiapkan data dan peta, juga untuk Cheviano Alputila, staf BPCB Ternate, atas bantuannya dalam analisis keramik. Terima kasih juga kepada masyarakat Loloda dan tak lupa terima kasih kepada bapak Mansyur Mustafa, tokoh masyarakat Loloda dan staf pengajar di Universitas Khairun, Ternate, atas beberapa masukan dan informasi yang memudahkan penulis dalam melakukan penelitian awal ini. 


\section{DAFTAR PUSTAKA}

Amal, A. M. (2010). Kepulauan Rempah-rempah Perjalalanan Sejarah Maluku Utara 1250-1950. Jakarta: Kepustakaan Populer Gramedia.

Ambary, H. M. (1998). Menemukan Peradaban Jejak Arkeologis Historis Islam di Indonesia. Jakarta: Logos Wacana Ilmu.

Andaya, L.Y. (1993). The World of Maluku. Honolulu: University of Hawaii.

Andaya, L. Y. (2015). Dunia Maluku, Indonesia Timur Pada Zaman Modern Awal. Yogyakarta: Penerbit Ombak.

Assegaf, U. M. (1974). Sedikit tentang Maluku Utara. Buletin IKMU Surabaya.

Handoko, W. (2008) Ekspansi dan Rivalitas Kekuasaan Islam: Pengaruhnya di Wilayah Siri Sori Islam, Pulau Saparua, Maluku Tengah. Kapata Arkeologi, 5(8), 1-22.

Handoko, W. (2009). Dinamika Budaya Islam di Wilayah Maluku Bagian Selatan. Kapata Arkeologi, 5(9), 14-31.

Handoko, W. (2013). Perniagaan dan Islamisasi di Wilayah Maluku. Kalpataru, 22(1), 17-29.

Handoko, W. (2017) Ekspansi Kekuasaan Islam Kesultanan Ternate di Pesisir Timur Halmahera Utara. Kapata Arkeologi, 13(1), 95-108.

Handoko, W., Mujabuddawat, M. A., Huwae, A., Latupapua, S., Manuputty, Y., \& Johannes, K. (2016). Laporan Penelitian: Tanah Kao: Menguak Identitas Asal Usul Komunitas, Sejarah dan Peradaban Islam di Halmahera Utara. Ambon: Balai Arkeologi Maluku.

Leirissa, R. Z. (1990). Masyarakat Halmahera dan Raja Jailolo: Studi tentang Sejarah Masyarakat Maluku Utara. Disertasi, Universitas Indonesia.

Leirissa, R. Z. (1996). Halmahera Timur dan Raja Jailolo: Pergolakan Sekitar Laut Seram Awal Abad Ke-19. Jakarta: Balai Pustaka.

Leirissa, R. Z. (2001). Jalur Sutera: IntegrasiLautDarat dan Ternate sebagai Bandar diJalur Sutera. In Yusuf Abdulrahman (Ed.), Ternate Bandar Jalur Sutera. Ternate: LinTas.

Mahirta. (1996a). The Development of Mare Pottery in Nothern Moluccas Context and its Recent Trading Network. Thesis, Australian National University.

Mahirta. (1996b). The Development of the Mare Pottery Tradition in the Northern Moluccas. In IPPA Congress (pp. 124-131).

Mansyur, M. (2007). Loloda dan Integritas Kesultanan Ternate (1945-1999). Skripsi, Universitas Khairun.

Mansyur, M. (2013). Transformasi Politik di Loloda Maluku Utara (1808-1945). Tesis, Universitas Padjajaran.

Mappanawang, A. L. (2012). Loloda Kerajaan Pertama Moluccas (Sejarah Kerajaan Loloda
Maluku). Tobelo: Yayasan Medika Mandiri Halmahera.

Putuhena, S. (1983). Struktur Pemerintahan Kesultanan Ternate dan Agama Islam. In Masinambow, E. K. M. (Ed.), Halmahera dan Raja Ampat. Jakarta: Leknas LIPI.

Putuhena, S. (2001). Proses Perluasan Agama Islam di Maluku Utara. In Abdulrahman, M. J. (Ed.), Ternate: Bandar Jalur Sutera. Ternate: LinTas.

Rahman, A. (2015). Struktur Politik Kerajaan Loloda diantara Minoritas Islam dan Mayoritas Kristen Abad XVII-XX. Alturas, XXI(2), 91-112.

Schiffer, B. M., Alan P. S., \& Timothy C. K. (1978). The Design of Archaeological Surveys. World Archaeology, 10(1), 1-28.

Sjah, M. (2005). Moloku Kie Raha dalam Perspektif Budaya dan Sejarah Masuknya Islam. Ternate: HPMT Press.

Tim Penelitian. (2014). Laporan penelitian: Arkeologi Islam di Wilayah Pesisir Timur Kabupaten Halmahera Utara. Ambon: Balai Arkeologi Maluku. Tidak terbit.

Tjandrasasmita, U. (2009). Arkeologi Islam Nusantara. Jakarta. Kepustakaan Populer Gramedia (KPG).

Tudoho, A. M. (2014). Tidore Pada Masa Kolonial Belanda pada Abad XVIII. Tesis, Universitas Gorontalo.

Yusuf, A. H. M. (2002). Kesultanan Ternate dalam "Jou Ngon Ka Dada Madopo Fangare Ngom Ka Alam Madiki” (Moti Verbond 1322). Manado: Media Pustaka. 